\title{
Stakeholder Information Sharing and Implementation of Sustainable Community Food Security Projects in Nyando Basin, Kenya
}

\author{
Onyango George Nyakoyo, Abuya Isaac Odhiambo* \\ Department of Open Learning Programmes University of Nairobi
}

DOI: $10.36348 /$ sjhss.2020.v05i02.002

| Received: 14.02.2020 | Accepted: 21.02.2020 | Published: 23.02.2020

*Corresponding author: Dr. Isaac Abuya

\section{Abstract}

Sharing agricultural information among stakeholders involved in community food security projects is believed to be critical to the implementation success of the projects. Information sharing on pest and disease control, markets and prices of agricultural produce, flood control, especially for flood prone regions like the Nyando basin, is critical for stakeholders involved in community food security programming Implementation of sustainable community food security projects is a major challenge not only in Kenya, but also in many developing countries affected by acute food insecurity. Anecdotal and empirical evidence suggest that sharing of agricultural information among agricultural stakeholder stakeholders may have a positive influence on implementation of sustainable community food security projects. However, few studies have established the association between stakeholder information sharing and implementation of community. The study was conducted in the Nyando basin of Western Kenya. The Nyando basin is one of the regions in Kenya that experiences serious food insecurity. The perennial flooding and with the basin exposes the families and communities in the Nyando Basin not only to food insecurity but also to diseases that cumulatively affect the productive capacity of the families and communities living within the basin. A cross-sectional study design was used. The target population was 769 people composed of members of three food security projects (cassava, sorghum and sweet potato projects), agricultural extension officers, county government officials, managers of non-governmental organizations providing technical support to community food security projects within the basin. A sample size of 260 was computed using Krecjie and Morgan [1] sample size estimation. Data was collected using questionnaire. Simple random sampling and stratified sampling procedures were used. Descriptive and inferential data were analysed. Descriptive statistics included frequencies, means and standard deviation, while inferential statistics included Pearson product moment correlation coefficient, coefficient of determination, ANOVA and regression coefficients. There was significant relationship between stakeholder information sharing and implementation of sustainable community food security projects $(\mathrm{r}=0.120$ and $\mathrm{p}=$ 0.061 ; thus, $\mathrm{p}$ value of $0.000<0.05$ ). It is recommended that stakeholder information sharing processes should be prioritized in community food security projects to make them sustainable. It is also recommended that stakeholder information sharing should be integrated in community food security policies and projects.

Keywords: Stakeholder Information Sharing, Food Security, Sustainable Community Food Security Projects, Nyando Basin.

Copyright @ 2020: This is an open-access article distributed under the terms of the Creative Commons Attribution license which permits unrestricted use, distribution, and reproduction in any medium for non-commercial use (NonCommercial, or CC-BY-NC) provided the original author and source are credited.

\section{INTRODUCTION}

Sustainable community food security projects experience major challenge not only in Kenya, but also in many developing countries affected by acute food insecurity. Anecdotal evidence suggests that stakeholder information sharing may have an influence on implementation of community food security projects. However, few studies have established the association between stakeholder information sharing and implementation of community. It is estimated that by 2011, 11 million Kenyans were suffering from chronic food insecurity, with four million people requiring emergency food assistance. It is also estimated that nearly $30 \%$ of children in Kenya are malnourished [2]. To address food insecurity in the country in a more sustainable manner, the government developed the National Food and Nutrition Policy in 2011.The National Policy proposes a number of policy interventions to address the food and nutritional challenges in Kenya. Among its other overarching strategies, the National Food and Nutrition Policy [3] recognize the critical role of local communities in addressing food insecurity in a sustainable way. 
Mobilization of community support to address the growing food and nutrition challenge in the country is identified by the national policy as a critical pillar of sustainable food and nutrition in Kenya, thereby centering sustainable community food security projects in the national policy discourse and interventions. The subsequent section presents review of literature on the concept of community food security and presents a rationale for stakeholder information sharing in community food security projects.

Implementation of community food security projects may face a number of challenges that require coordinated information sharing among stakeholders involved in the initiatives. Especially for environmentally compromised regions like Nyando Basin, timely information on floods and their control and management [4], information on effective postharvest management, sharing of timely and targeted information on markets and prices, evidence information on disease and pest control [5-8] and information on sustainable farming practices, may facilitate the effective implementation of community food security projects.

\section{Salience of Community Food Security and Stakeholder Information Sharing}

Sustainable community food security is a relatively new food security-promoting strategy that considers all the factors within a region or community's food system that influence the availability, cost, and quality of food to area households, particularly those in lower income communities [9]. They argue that since sustainable community food security focuses on regional and local food systems, it is concerned with the full range of food chain events including agriculture, the availability of supermarkets and other affordable outlets for quality food, the involvement of the wider citizenry and local and state governments in seeking solutions to food insecurity, and the services and environments that encourage healthy food choices including schools, nutrition service providers, and commercial food operations. Based on these broader conceptualizations, it is evident that sustainable community food security projects encompass a wide variety of community-based efforts to increase the quantity, quality, and affordability of food for local residents, especially for poor members of the community.

Dowler and Caraher [10] argue that sustainable community food projects are hard to define and characterise consistently. In their view, termsustainable community food projects, is used by a range of professionals and sectors to conceptualize local food and nutrition security initiatives that share common characteristics: food (its production, preparation or consumption), local involvement (management, delivery, paid/unpaid workers) and state support (funding, space, professional input, transport, equipment). Dowler and Caraher [10] posits that sustainable community food security projects have varying management and organisational structures, and can encompass local activities run by volunteers to those where a statutory worker has been given time to engage with the local community in developing food; and the funding and support for these local initiatives can come from local authorities and other charitable sources [10]. Campbell, Carlisle-Cummins, and Feenstra [11] posit that although sustainable community food security projects vary widely in their focus, scope, and motivation, sustainable community food security projects and their efforts are modest and initiated in response to specific community needs, these projects are broad based social and economic experiment in how to build food economies that are more locally based and increasingly self-reliant.

According to Campbell et al. [12], the persistent and strategic challenges facing sustainable community food security projects are three fold: (1) an economic challenge rooted in the difficulty of finding price points that work for farmers while ensuring that low-income consumers have access to healthy food and food system workers have decent wages and benefits; (2) a social challenge to confront racial and class bias while forging practical solutions; and (3) a political challenge of reconciling "insider" and "outsider" strategies, the former emphasizing incremental reform and the latter systemic change. These challenges resist simple solutions, but progress can be made if researchers and practitioners join forces. The nature of these challenges calls for effective stakeholder information sharing in food security projects since available evidence suggests an association between stakeholder information sharing and effective implementation of sustainable community food security projects. Campbell, Carlisle-Cummins, and Feenstra [11] framework is relevant for not only understanding the persistent and strategic challenges that face sustainable community food projects but also provides a rationale for effective engagement of stakeholders in sustainable community food projects.

Available evidence suggests that the success of sustainable community food systems depend greatly on stakeholder information sharing strategies 13, 14, 9]. The salience of stakeholder information sharing in sustainable community food projects is inherent in the definition, nature and themes of sustainable community food and sustainable community food security projects. In a comprehensive research of the persistent and strategic challenges facing sustainable community food security projects, Campbell, Carlisle-Cummins and Feenstra [11] developed a sustainable community food system bibliography that identified persistent and strategic challenges facing sustainable community food security stakeholders. These challenges are economic, social, and political in nature [11]. Marsden and Morley 
[15] posit that there is a growing recognition among scholars and policy advisors in food systems of the need to re-examine the interconnections and linkages between food security, sustainability, sovereignty and justice in the provision, supply, allocation and consumption of food. These interconnections and linkages 'in the sustainable community food systems require the effective engagement of stakeholders. Addressing food security at the community level, and especially in sustainable community food systems, require the coordinated support and meaningful engagement of stakeholders: stakeholders need to have a shared understanding of the determinants of food insecurity in their communities, who is heavily affected and the strategies that the community members need to put in place to address food insecurity sustainably.

Sustainable community food security interventions may have some untoward impact on the environment $[16,17]$. The farming practices adopted by farmers in a sustainable community food security project, for instance may have an impact on the environment. The decision for example, whether to use organic fertilizers or to use commercial fertilizers in community farm systems, need the active engagement of diverse stakeholders with a stake in the sustainable community food security systems or projects. Whereas some stakeholders in the sustainable community food systems may favour the application of organic fertilizers, some with commercial interests may favour the use of commercial fertilizers, some of which have negative effects of the soil and water sources for the community.

To ensure sustainable community food security projects, stakeholders involved in sustainable community food systems must focus on promoting proenvironmental behaviors in their food security programming. Sustainable community food security projects must identify negative environmental impacts that their sustainable community food systems may precipitate. Effective involvement of stakeholders in sustainable community food security programming is therefore critical for sustainable food systems and projects at the community level. To address the 'interconnections and linkages 'in the sustainable community food systems [15], especially the interconnections and linkages between sustainable community food security and sustainable agricultural practices may require effective engagement of stakeholders.

Food sovereignty is a critical component of what Marsden and Morley [15] refer to as 'interconnections and linkages 'in the sustainable community food systems. The term food sovereignty, coined by Via Campesina in 1996, posits that the people who produce, distribute, and consume food should control the mechanisms and policies of food production and distribution, rather than the corporations and market institutions they believe have come to dominate the global food system. The term also encompasses the right of peoples to healthy and culturally appropriate food and their right to define their own food and agriculture systems. The phrase "culturally appropriate" signifies that the food that is available and accessible for the population should fit with the cultural background of the people consuming it. The realization of food sovereignty at the community level requires the active engagement of stakeholders involved in sustainable community food security programming.

Food sovereignty is intuitively political in conception $[18,12]$. Thus to assure the realization of food sovereignty in sustainable community food systems and projects require a comprehensive understanding of the politics and the broader political economy of food insecurity and food security. A number of scholars have persuasively articulated the centrality of politics and power distribution is sustainable community food projects $[2,19,20]$. Stakeholders are people with conflicting interests: there are stakeholders who benefit when community members are food insecure. Thus, any intervention at the community levels that is likely to address food insecurity in a sustainable manner is likely to resist any food security intervention and programming at the community level. Even beyond concern about the power of commercial food value chain players, the power dynamics between different genders at the community level may affect the implementation and overall performance of sustainable community food security systems or projects. In a number of agricultural oriented developing countries like Kenya, men wield more decision making powers compared to women. Again, while most of the farm labour in sustainable community food systems is provided by women, men mostly make decisions on how the produce and the income from the farms are distributed.

The power asymmetry in sustainable community food systems may unwittingly affect the performance of sustainable community food security projects. It is important to identify and understand the differential power dynamics presented by different stakeholders involved in a sustainable community food security system or project. This calls for active identification of the different stakeholders and designing effective stakeholder information sharing strategies in the sustainable community food security projects. Food sovereignty and its attendant outcomes are therefore part of the critical components of the 'interconnections and linkages 'in the sustainable community food systems [15], and active involvement of stakeholders in the sustainable community food value chains is critical and important for the successful implementation and performance of sustainable community food security systems and projects. 


\section{RESEARCH METHODOLOGY}

The study was conducted in the Nyando basin of Western Kenya. The Nyando basin is one of the regions in Kenya that experiences serious food insecurity. The perennial flooding and with the basin exposes the families and communities in the Nyando Basin not only to food insecurity but also to diseases that cumulatively affect the productive capacity of the families and communities living within the basin. A cross-sectional study design was used. The target population was 769 people composed of members of three food security projects (cassava, sorghum and sweet potato projects), agricultural extension officers, county government officials, managers of nongovernmental organizations providing technical support to community food security projects within the basin.

Using Krecjie and Morgan sample size estimation, a sample size of 260 was found to be sufficient for this study. Data was collected using questionnaire. Simple random sampling and stratified sampling procedures were used. Data was collected using a self-administered questionnaire. Simple random and stratified sampling procedures were used. Descriptive and inferential statistics were computed using SPSS. Descriptive statistics included frequencies, percentages, means and standard deviations; while inferential statistics included Pearson's correlation(r), co-efficient of determination $\left(\mathrm{R}^{2}\right)$, Anova Test ( $\mathrm{p}$ value) and Beta coefficients $(\beta)$. Both descriptive and inferential statistics were analysed using SPSS.

\section{RESULTS AND DISCUSSION}

The purpose of the study was to establish the relationship between stkeholder information sharing and implementation of sustainable community food security projects. This section presents the findings of the study.

Table-1: Demographic Profile of Research Participants

\begin{tabular}{|c|c|c|c|}
\hline Particulars & Category & Frequency & Percentage \\
\hline \multirow[t]{3}{*}{ Gender } & Female & 97 & 39.6 \\
\hline & Male & 148 & 60.4 \\
\hline & Total & 245 & 100.0 \\
\hline \multirow[t]{6}{*}{ Participant age } & $20-29$ & 16 & 6.5 \\
\hline & $30-39$ & 30 & 12.2 \\
\hline & $40-49$ & 91 & 37.1 \\
\hline & $50-59$ & 71 & 29.0 \\
\hline & $60-$ Above & 37 & 15.1 \\
\hline & Total & 245 & $\mathbf{1 0 0 . 0}$ \\
\hline \multirow[t]{8}{*}{ Education level } & No Education & 6 & 2.4 \\
\hline & Primary & 109 & 44.5 \\
\hline & Secondary/O-Level & 72 & 29.4 \\
\hline & A-level & 7 & 2.9 \\
\hline & Diploma & 42 & 17.1 \\
\hline & Bachelor's degree & 6 & 2.4 \\
\hline & Master's degree & 3 & 1.2 \\
\hline & Total & 245 & 100.0 \\
\hline \multirow[t]{4}{*}{ Marital Status } & Married & 217 & 88.6 \\
\hline & Single/Divorced & 9 & 3.7 \\
\hline & Widow/Widower/Separated & 19 & 7.8 \\
\hline & Total & 245 & 100.0 \\
\hline \multirow{6}{*}{$\begin{array}{l}\text { No. of years involved in Sustainable } \\
\text { community food Security Projects }\end{array}$} & $0-5$ years & 138 & 56.3 \\
\hline & $6-10$ years & 67 & 27.3 \\
\hline & 11- 20 years & 31 & 12.7 \\
\hline & 21- 30 years & 9 & 3.7 \\
\hline & $31-50$ years & 0 & 0.0 \\
\hline & Total & 245 & 100.0 \\
\hline
\end{tabular}

Table 1 presents the demographic data of the study respondents. The study sought information on the respondents 'gender, participant's age, education level, marital status, and number of years actively involved with sustainable community food security projects. Out of the 245 respondents, 97(39.6\%) were female and $148(60.4 \%)$ were male. The data suggest that more women are actively involved with sustainable community food security projects than men. Out of 245 respondents, 91(37.1\%) were aged between 40-49 years; 71(29\%) were aged between 50-59 years; $37(15.1 \%)$ were above 60 years; $30(12.2 \%)$ were aged between 30-39 years; $16(6.5 \%)$ were aged between 20 29 years. The data on age of respondents suggests that more productive community member is involved in sustainable community food security projects. Out of 254 respondents, $109(44.5 \%)$ had primary level certificate, primary level holders, $72(29.4 \%)$ were 
secondary/O-Level holders, 42(17.1\%) were diploma holders, 7(2.9\%) A-Level holders, 6(2.4\%) had bachelor degree while a3 (1.2\%) had master degree. The data on education indicates that majority of the respondents involved in sustainable community food security projects are primary school certificate level holders followed by secondary school level certificate holders. On marital status, out of 245 respondents, $217(88.6 \%)$ were married, $19(7.8 \%)$ were widows/widower/ separated/divorced, $9(3.7 \%)$ were single.

The study also sought information on the number of years the respondents have been involved in sustainable community food security projects. Out of 245 respondents, $138(56.3 \%)$ have been involved with sustainable community food security projects for between 0-5 years, 67(27.3\%) had been involved for between 6-10 years, 31(12.7\%) had been involved with the projects for between 11-20 years, $9(3.7 \%)$, between 21-30 years. The findings on the number of years of active involvement in sustainable community food projects suggest that sustainable community food security projects are recent developments in sustainable community food security programming in the Nyando basin.

\section{Analysis of Implementation of Community Food Security Projects}

The study sought the perspectives of the implementation of community food security projects. Five positively worded statements on implementation of sustainable community food security projects were assessed using a 5-Likert scale.

Table-5: Descriptive Statistics on the Implementation of Community Food Security Projects

\begin{tabular}{|l|c|c|c|c|c|c|c|c|}
\hline Sub-Variables & SD & D & UD & A & SA & Total & Mean & SD \\
\hline $\begin{array}{l}\text { ICF'SP1 - Community food security } \\
\text { projects are implemented in time }\end{array}$ & 1 & 3 & 3 & 69 & 169 & 245 & 4.64 & 0.615 \\
\hline & $0.4 \%$ & $1.2 \%$ & $1.2 \%$ & $28.2 \%$ & $69.0 \%$ & $100.0 \%$ & & \\
\hline $\begin{array}{l}\text { ICFSP2 - Community food security } \\
\text { projects are completed in time }\end{array}$ & 1 & 5 & 3 & 75 & 161 & 245 & 4.59 & 0.663 \\
\hline & $0.4 \%$ & $2.0 \%$ & $1.2 \%$ & $30.6 \%$ & $65.7 \%$ & $100.0 \%$ & & \\
\hline $\begin{array}{l}\text { ICFSP3 - Stakeholders are satisfied } \\
\text { with the implementation of food } \\
\text { security projects }\end{array}$ & 0 & 5 & 5 & 99 & 136 & 245 & 4.49 & 0.644 \\
\hline & $0.0 \%$ & $2.0 \%$ & $2.0 \%$ & $40.4 \%$ & $55.5 \%$ & $100.0 \%$ & & \\
\hline $\begin{array}{l}\text { ICFSP4 - Community food projects } \\
\text { are cost effective }\end{array}$ & 2 & 5 & 10 & 74 & 154 & 245 & 4.52 & 0.744 \\
\hline & $0.8 \%$ & $2.0 \%$ & $4.1 \%$ & $30.2 \%$ & $62.9 \%$ & $100.0 \%$ & & \\
\hline $\begin{array}{l}\text { ICFSP5 - Community food security } \\
\text { projects promote environmental } \\
\text { sustainability }\end{array}$ & 2 & 5 & 7 & 79 & 152 & 245 & 4.53 & 0.727 \\
\hline & $0.8 \%$ & $2.0 \%$ & $2.9 \%$ & $32.2 \%$ & $62.0 \%$ & $100.0 \%$ & & \\
\hline
\end{tabular}

Item ICF'SP1 sought information from the respondents on the extent to which they agreed that community food security projects are implemented in time. Out of $245,169(69.0 \%)$ strongly agreed that community food security projects are implemented in time; $69(28.2 \%)$ agreed with the statement, $3(1.2 \%)$ were neutral, $3(1.2 \%)$ disagreed while only $1(0.4 \%)$ strongly disagreed with the statement that community food security projects are implemented in time. The mean for the statement was 4.64, and the standard deviation was 0.615 suggesting that most respondents agreed that community food security projects are implemented in time.

Item ICF'SP2 sought information from the respondents on the extent to which they agreed that community food security projects are completed in time. Out of 245 respondents who responded to the item $161(65.7 \%)$ strongly agreed that community food security projects are completed in time, 75(30.6\%) agreed with the statement, $5(2.0 \%)$ disagreed, $3(1.2 \%)$ were neutral while only $1(0.4 \%)$ strongly disagreed with the statement. The mean for the statement was 4.59 and the standard deviation was 0.663 , suggesting that most respondents agreed that community food security projects are completed in time.

Item ICF'SP3 sought information from the respondents on the extent to which they agreed with the statement that stakeholders are satisfied with the implementation of food security projects. Out of 245 respondents who responded to the item154 (62.9\%) strongly agreed that stakeholders are satisfied with the implementation of food security projects, 99(40.4\%) agreed with the statement, $5(2.0 \%)$ disagreed, $5(2.0 \%)$ were neutral, while $0(0.0 \%)$ strongly disagreed with the statement. The mean for the statement was 4.49 and the standard deviation was 0.0 .644 , suggestingg that most respondents agreed that stakeholders are satisfied with the implementation of food security projects.

Item ICF'SP4 sought information from the respondents on the extent to which they agreed with the statement that community food projects are cost 
effective. Out of 245 respondents who responded to the item $152(62.9 \%)$ strongly agreed that that community food projects are cost effective, 74(30.2\%) agreed with the statement, $10(4.1 \%)$ were undecided, $10(4.1 \%)$ disagreed, while $5(2.0 \%)$ strongly disagreed with the statement. The mean for the statement was 4.55 and the standard deviation was 0.0 .644 , suggestingg that most respondents agreed that community food projects are cost effective. The mean for the statement was 4.52 and the standard deviation was 0.0 .744 , suggestingg that most respondents agreed that community food projects are cost effective.

Item ICF'SP5 sought information from the respondents on the extent to which they agreed with the statement that community food security projects promote environmental sustainability. Out of 245 respondents who responded to the item 152(62.0\%) strongly agreed that that community food security projects promote environmental sustainability,
$79(32.2 \%)$ agreed with the statement, $7(2.9 \%)$ were undecided, $5(2.0 \%)$ disagreed, while only $2(0.8 \%)$ strongly disagreed with the statement. The mean for the statement was 4.53 and the standard deviation was 0 . 0.644 , suggestingg that most respondents agreed that community food projects are cost effective. The mean for the statement was 4.52 and the standard deviation was 0.0 .727 , suggestingg that most respondents agreed that community food security projects promote environmental sustainability.

\section{Analysis of Stakeholder Information Sharing on Implementation of Community Food Security Projects}

To measure the extent stakeholders' information sharing process influences the implementation of community food security projects, five statements on the indicators were developed in the administered questionnaire using a five Likert scale.

Table-2: Descriptive Statistics on Stakeholder Information Sharing on Implementation of Community Food Security Projects

\begin{tabular}{|c|c|c|c|c|c|c|c|c|}
\hline Sub-Variables & SD & D & UD & $\mathbf{A}$ & SA & Total & Mean & SD \\
\hline \multirow{2}{*}{$\begin{array}{l}\text { SISP1 - Stakeholder information sharing on } \\
\text { flood control and management enhances } \\
\text { timely implementation of sustainable } \\
\text { community food security projects }\end{array}$} & 1 & 1 & 8 & 69 & 166 & 245 & 4.62 & 0.612 \\
\hline & $0.4 \%$ & $0.4 \%$ & $3.3 \%$ & $28.2 \%$ & $678 \%$ & $100.0 \%$ & & \\
\hline \multirow{2}{*}{$\begin{array}{l}\text { SISP2 - Stakeholder information sharing on } \\
\text { sharing on post-harvest management } \\
\text { enhances timely completion of sustainable } \\
\text { community food projects }\end{array}$} & 0 & 1 & 5 & 92 & 147 & 245 & 4.57 & 0.558 \\
\hline & $0.0 \%$ & $0.4 \%$ & $2.0 \%$ & $37.6 \%$ & $60.0 \%$ & $1000 \%$ & & \\
\hline \multirow{2}{*}{$\begin{array}{l}\text { SISP3 - Stakeholder information sharing on } \\
\text { markets and prices makes community food } \\
\text { security projects to be cost effective and } \\
\text { profitable }\end{array}$} & 16 & 38 & 41 & 105 & 45 & 245 & 3.51 & 1.151 \\
\hline & $6.5 \%$ & $15.5 \%$ & $16.7 \%$ & $42.9 \%$ & $18.4 \%$ & $100.0 \%$ & & \\
\hline \multirow{2}{*}{$\begin{array}{l}\text { SISP4 - Stakeholder information sharing on } \\
\text { pest and disease control improves } \\
\text { sustainability of community food security } \\
\text { projects }\end{array}$} & 0 & 2 & 1 & 75 & 167 & 245 & 4.66 & 0.531 \\
\hline & $0.0 \%$ & $0.8 \%$ & $0.4 \%$ & $30.6 \%$ & $68.2 \%$ & $100.0 \%$ & & \\
\hline \multirow{2}{*}{$\begin{array}{l}\text { SISP5 - Stakeholder information sharing on } \\
\text { sustainable farming practices and agricultural } \\
\text { extension services enhances their satisfaction } \\
\text { with the performance of community food } \\
\text { security projects }\end{array}$} & 17 & 44 & 34 & 107 & 43 & 245 & 3.47 & 1.175 \\
\hline & $6.9 \%$ & $18.0 \%$ & $13.9 \%$ & $43.7 \%$ & $17.6 \%$ & $100.0 \%$ & & \\
\hline
\end{tabular}

Table 2 presents the descriptive statistics of the respondents' perspectives on stakeholder information sharing on implementation of sustainable community food security projects in the Nyando basin.

Item SISP 1 sought information on the extent to which they agreed that stakeholder information sharing on flood control and management enhances timely implementation of sustainable community food security projects. Out of 254 respondents, 166(67.8\%) strongly agreed that stakeholder information sharing on flood control and management enhances timely implementation of sustainable community food security projects, $69(28.2 \%)$ agreed stakeholder information sharing on flood control and management enhances timely implementation of sustainable community food security projects, $8(3.3 \%)$ were neutral, $1(0.4 \%)$ disagreed with the statement and only 
$1(0.4 \%)$ strongly disagreed with the statement that $\mathrm{s}$ stakeholder information sharing on flood control and management enhances timely implementation of sustainable community food security projects. The mean and the standard deviation for item SEP1 was 4.62 and 0.612 , suggesting that stakeholder information sharing on flood control and management enhances timely implementation of sustainable community food security projects.

Item SISP 2 sought information on the extent to which they agreed that stakeholder information sharing on post-harvest management enhances timely completion of sustainable community food projects. Out of 254 respondents, 147(60.0\%) strongly agreed that stakeholder information sharing on post-harvest management enhances timely completion of sustainable community food projects, 92(37.6\%) agreed stakeholder information sharing on flood control and management enhances timely implementation of sustainable community food security projects, $5(2.0 \%)$ were neutral, $1(0.4 \%)$ disagreed with the statement and $0(0.0 \%)$ strongly disagreed with the statement that stakeholder information sharing on post-harvest management enhances timely completion of sustainable community food projects. The mean and the standard deviation for item SEP2 was 4.57and 0.558, respectively, suggesting that stakeholder information sharing on post-harvest management enhances timely completion of sustainable community food projects.

Item SISP 3 sought information on the extent to which they agreed that stakeholder information sharing on markets and prices makes community food security projects to be cost effective and profitable. Out of 254 respondents, 45(18.4\%) strongly agreed that stakeholder information sharing on markets and prices makes community food security projects to be cost effective and profitable 105(42.9\%) agreed that stakeholder information sharing on markets and prices makes community food security projects to be cost effective and profitable, 41(16.7\%) were neutral, $38(15.5 \%)$ disagreed with the statement and $16(6.5 \%)$ strongly disagreed with the statement that stakeholder information sharing on markets and prices makes community food security projects to be cost effective and profitable. The mean and the standard deviation for item SEP3 was 3.51 and 1.151, respectively, suggesting that stakeholder information sharing on markets and prices makes community food security projects to be cost effective and profitable.

Item SISP 4 sought information on the extent to which they agreed that stakeholder information sharing on pest and disease control improves sustainability of community food security projects. Out of 254 respondents, $167(68.2 \%)$ strongly agreed that stakeholder information sharing on pest and disease control improves sustainability of community food security projects, $75(30.6 \%)$ agreed that stakeholder information sharing on pest and disease control improves sustainability of community food security projects, $1(0.4 \%)$ were neutral, $2(0.8 \%)$ disagreed with the statement and $0(0.0 \%)$ strongly disagreed with the statement that s stakeholder information sharing on pest and disease control improves sustainability of community food security projects. The mean and the standard deviation for item SEP4 was 4.66 and 0.531 , respectively, suggesting that stakeholder information sharing on pest and disease control improves sustainability of community food security projects.

Item SISP 5 sought information on the extent to which they agreed that stakeholder information sharing on sustainable farming practices and agricultural extension services enhances their satisfaction with the performance of community food security projects. Out of 254 respondents, 43(17.6\%) strongly agreed that stakeholder information sharing on sustainable farming practices and agricultural extension services enhances their satisfaction with the performance of community food security projects, $107(43.7 \%)$ agreed that stakeholder information sharing on sustainable farming practices and agricultural extension services enhances their satisfaction with the performance of community food security projects, 34(13.9\%) were neutral, 44(18.0\%) disagreed with the statement and 17(6.9\%) strongly disagreed with the statement that stakeholder information sharing on sustainable farming practices and agricultural extension services enhances their satisfaction with the performance of community food security projects. The mean and the standard deviation for item SEP5 was 3.47and 1.175, respectively, suggesting a moderate agreement that stakeholder information sharing on sustainable farming practices and agricultural extension services enhances their satisfaction with the performance of community food security projects.

\section{CORRELATION ANALYSIS}

Pearson product moment correlation coefficient was computed to establish the existence or non- existence of significant relationship the degree or strength of association between stakeholder information sharing and implementation of community food security projects based on the perspectives of the research participants. 
Table-3: Pearson Correlation

\begin{tabular}{|l|l|c|c|}
\hline \multicolumn{2}{|c|}{} & $\begin{array}{c}\text { Stakeholder } \\
\text { Information Sharing }\end{array}$ & $\begin{array}{c}\text { Implementation of community } \\
\text { food security projects }\end{array}$ \\
\hline \multirow{2}{*}{$\begin{array}{l}\text { Stakeholder Information } \\
\text { Sharing }\end{array}$} & Pearson Correlation & 1 & 0.120 \\
\cline { 2 - 4 } & Sig. (2-tailed) & & 0.061 \\
\cline { 2 - 4 } & $\mathrm{N}$ & 245 & 245 \\
\hline \multirow{2}{*}{$\begin{array}{l}\text { Implementation of community } \\
\text { food security projects }\end{array}$} & Pearson Correlation & 0.120 & 1 \\
\cline { 2 - 4 } & Sig. (2-tailed) & 0.061 & 245 \\
\cline { 2 - 4 } & $\mathrm{N}$ & 245 & \\
\hline \multicolumn{2}{|l|}{ Note: $* *$ Correlation is significant at the 0.01 level (2-tailed) i.e. 99\% level significance } \\
\hline
\end{tabular}

Table 3 presents the Pearson correlation of stakeholder information sharing and implementation of community food security projects. Analysis from the table shows a positive correlation between the variables as $r=0.120$ and $p=0.061$; thus, $p$ value of $0.000<0.05$ is significant. The findings indicate that there is significant relationship between stakeholder information sharing and implementation of community food security projects. The findings of this study are consistent with the reviewed empirical studies that suggest a relationship between stakeholder information sharing and of implementation of sustainable community food systems $[13,14,9]$.

\section{Regression Analysis}

To find the amount of variation in the implementation of sustainable community food security projects, which explains its association with stakeholder information sharing, the coefficient of determination $\left(\mathrm{R}^{2}\right)$ was computed. The coefficient was also computed to help in understanding or explaining the amount of variation in the implementation of sustainable community food security projects.

Table-4: Model Summary

\begin{tabular}{|c|c|c|c|c|}
\hline Model & $\mathbf{R}$ & $\mathbf{R}^{\mathbf{2}}$ & Adjusted $\mathbf{R}^{\mathbf{2}}$ & Std. Error of the Estimate \\
\hline 1 & $0.120^{\mathrm{a}}$ & 0.014 & 0.010 & 0.48043 \\
\hline
\end{tabular}

Table 4 presents the model summary of the association between stakeholder information sharing and implementation of sustainable community food security projects. The coefficient of determination $\mathrm{R}^{2}=$ $0.014(1.4 \%)$ suggest that the amount of variance in implementation of sustainable community food security projects is explained by stakeholder information sharing in the food security projects. The model results are consistent with the reviewed empirical studies that suggest a relationship between stakeholder information sharing and of implementation of sustainable community food systems $[13,14,9]$.

Table-5: Analysis of Variance - ANOVA ${ }^{\mathrm{a}}$

\begin{tabular}{|c|c|c|c|c|c|c|}
\hline \multicolumn{2}{|c|}{ Model } & Sum of Squares & df & Mean Square & $\mathbf{F}$ & Sig. \\
\hline \multirow[t]{3}{*}{1} & Regression & 0.818 & 1 & 0.818 & 3.544 & $0.061^{b}$ \\
\hline & Residual & 56.088 & 243 & 0.231 & & \\
\hline & Total & 56.906 & 244 & & & \\
\hline \multicolumn{7}{|c|}{ Note: ${ }^{\text {a }}$ Dependent Variable: Implementation of community food security projects } \\
\hline
\end{tabular}

From the above analysis of the Anova, it is evident that the significance of the relationship between stakeholder information sharing and implementation of community food security projects or the $\mathrm{p}$ value stands at 0.061 , which is more than 0.05 . The findings of this study are inconsistent with the reviewed empirical studies that suggest a relationship between stakeholder information sharing and of implementation of sustainable community food systems [13, 14, 9].

Table-6: Regression Coefficients ${ }^{\mathrm{a}}$

\begin{tabular}{|l|l|l|l|l|l|l|}
\hline \multicolumn{2}{|l|}{ Model } & Unstandardized Coefficients & Standardized Coefficients & t & Sig. \\
\hline \multicolumn{2}{|c|}{1} & B & Std. Error & Beta & & \\
\hline \multirow{2}{*}{1} & (Constant) & 4.039 & 0.276 & & 14.630 & 0.000 \\
\cline { 2 - 6 } & Stakeholder Information Sharing & 0.124 & 0.066 & 0.120 & 1.883 & 0.061 \\
\hline
\end{tabular}

From the results, the analysis returns $\beta$ coefficient constant of 4.039 and predictive variable of 0.124 . This means that a 1-point increase on stakeholder information sharing corresponds to 0.353 points increase on the implementation of community food security projects. Hence we can compute the dependent variable through the formula; Dependent $=4.039+$ (0.276 x stakeholder information sharing). Since all $\beta$ 
coefficients are positive values, it is sensible to conclude that higher values of stakeholder information sharing leads to higher values of the delivery of implementation of community food security projects. The findings of this study are consistent with the reviewed empirical studies that suggest a relationship between stakeholder information sharing and of implementation of sustainable community food systems $[13,14,9]$.

\section{CONCLUSION AND RECOMMENDATIONS}

The objective of the study was to examine the relationship between stakeholder information sharing and implementation of sustainable community food security projects. The study found statistically significant relationship between stakeholder information sharing and implementation of sustainable community food security projects (as $\mathrm{r}=0.120$ and $\mathrm{p}=$ 0.061 ; thus, $\mathrm{p}$ value of $0.000<0.05$ ). It is recommended that stakeholder information sharing should be enhanced in sustainable community food security projects to promote timely implementation and completion of sustainable community food security projects, reduce the cost of implementation, and ensure sustainable farming practices. It is also recommended that stakeholder information sharing should be integrated in sustainable community food security policies and projects.

\section{REFERENCES}

1. Krejcie, R. V., \& Morgan, D. W. (1970). Determining sample size for research activities. Educational and psychological measurement, 30(3), 607-610.

2. Alkon, A. H., \& Mares, T. M. (2012). Food sovereignty in US food movements: Radical visions and neoliberal constraints. Agriculture and Human Values, 29(3), 347-359.

3. Allen, P. (2010). Realizing justice in local food systems. Cambridge Journal of Regions, Economy and Society, 3(2), 295-308.

4. Osbahr, H., Twyman, C., Adger, W. N., \& Thomas, D. S. (2008). Effective livelihood adaptation to climate change disturbance: scale dimensions of practice in Mozambique. Geoforum, 39(6), 19511964.

5. Teng, P. S., \& Krupa, S. V. (1980). Assessment of losses which constrain production and crop improvement in agriculture and forestry. Proceedings of the EC Stakman Commemorative Symposium. University of Minnesota, Minneapolis, Minnesota. In Assessment of losses which constrain production and crop improvement in agriculture and forestry. Proceedings of the EC Stakman Commemorative Symposium. University of Minnesota, Minneapolis, Minnesota. (No. 7).

6. Teng, P. S. (Ed.). (1987). Crop loss assessment and pest management. St Paul: APS Press.
7. Oerke, E. C., Dehne, H. W., Schönbeck, F., \& Weber, A. (1994). Crop production and crop protection. Estimated losses in major food and cash crops. Amsterdam: Elsevier.

8. Oerke, E. C. (2006). Crop losses to pests. Journal of Agricultural Science, 144, 31

9. Lang, T. (1999b). Food policy for the 21st century: Can it be both radical and reasonable? In for hunger-proof cities: Sustainable urban food systems, edited by Mustafa Koc, Rod MacRae, Luc J. A. Mougeot, and Jennifer Welsh. Ottawa, Canada: International Development Research Centre.

10. Dowler, E., \& Caraher, M. (2003). Local food projects: The new philanthropy? The Political Quarterly, 74(1), 57-65.

11. Campbell, D. C., Carlisle-Cummins, I., \& Feenstra, G. (2013). Sustainable community food systems:

Strengthening the research-to-practice continuum. Journal of Agriculture, Food Systems, and Community Development, 3(3),121-138.http:// dx.doi.org/10.5304/jafscd.2013.033.008.

12. Campbell, M. C. (2004). Building a Common Table: The Role for Planning in Sustainable community food Systems. Journal of Planning Education and Research, 23:341-355.

13. Hassanein, N. (2003). Practicing food democracy: A pragmatic politics of transformation. Journal of Rural Studies 19(1): 77-86.

14. Kloppenburg, J., Lezberg, S., De Master, K., Stevenson, G. W., \& Hendrickson, J. (2000). Tasting food, tasting sustainability: Defining the attributes of an alternative food system with competent, ordinary people. Human Organization, 59(2): 177-86.

15. Marsden, T., \& Morley, A. (2010).” Current Food Questions and Their Scholarly Challenges: Creating and Framing a sustainable Food Paradigm" in Sustainable Food Systems: Building a New Paradigm. Terry Marsden and Adrian Morley (Eds,) 2010. Routledge.

16. Ericksen, P. J. (2008). Conceptualizing food systems for global environmental change research. Global environmental change,18(1), 234-245.

17. Defries, R.S., Foley, J.A., Asner, G.P. (2004). Land-use choices: balancing human needs and ecosystem function. Frontiers in Ecology and the Environment, 2, 249-257.

18. Schanbacher, W.D. (2010). The Politics of Food: The Global Conflict between Food Security and Food Sovereignty. Praeger.

19. Anderson, M. D. (2008). Rights-based food systems and the goals of food systems reform. Agriculture and Human Values, 25: 593-608.

20. Heynen, N., Kurtz, H.E., \& Trauger, A. (2012). Food justice, hunger and the city. Geography Compass, 6(5), 304-311. 